\title{
KERNICTERUS IN JAPAN-A REPORT OF FOUR CASES
}

\author{
TADAYOSHI KOBAYASHI and YONOSUKE WATANABE \\ Department of Pathology, School of Medicine, \\ Keio University
}

Kernicterus is a disease of newborn infants characterized by yellow staining of the basal ganglia of the brain. While in Europe and America, not a few cases of kernicterus have been reported, its occurrence in Japan seems to be very rare. Prior to 1950 there was no reported case of kernicterus in Japan. In 1951 we (14) reported four cases of kernicterus, which are described in this report, and M. Furuta and S. Kambe ${ }^{(4)}$ reported five cases of kernicterus immediately after our first publication. These nine cases were the first descriptions of kernicterus in Japan.

\section{CASE REPORT}

Case 1. (No. 3493): A boy, weighing $2220 \mathrm{Gm}$., was born after 35 weeks gestation. He appeared healthy despite premature birth. Moderate icterus was noticed six days after birth. The boy died the next day with an attack of dyspnoea. His father was of blood group OM.CDe and the mother of group BM.CDe. The blood Wassermann reaction of the mother was strongly positive. Her first pregnancy terminated in a nonviable baby at the term. The second pregnancy terminated in an abortion on the fourth month. The boy reported here was her third child.

Necropsy (14 hours after death): The skin and the mucous membranes were moderately jaundiced. No edema and petechial hemorrhage was observed.

The brain weighed $300 \mathrm{Gm}$. The blood vessels of the meninges were strongly injected. On section, nucleus hypothalamicus, hippocampus, the floor of the fourth ventricle, nucleus olivaris inferior, nuclei cerebelli were stained symmetrically deep yellow. Thalamus, putamen and pars pallida were also stained yellow but in lesser degree than above mentioned ganglia. Cortex and nucleus caudatus were not yellow. The white matter was entirely free from icterus. On microscopic examination of the yellow stained portions, among the ganglion cells with normal appearance one could readily find the cells filled with abundant light yellow granular pigments, In these cells the nucleus showed of ten degenerative changes such as 
pyknosis or karyolysis. The precipitation of the yellow granular pigments was observed as well in the ganglion cells as in the glia cells. The yellow pigment granules were also seen scattered in the intercellular substance, but there was no evidence that these pigment granules were arranged parallel to the direction of axis cylinders.

The liver, weighing $110 \mathrm{Gm}$., was grossly normal. Microscopically the lobules were well preserved. The sinusoids were somewhat dilated. The liver cell cords were narrow but not dissociated. The liver cells showed relatively marked hydropic degeneration. The fatty degencration was slight. In the'peripheries of the lobules moderate hemosiderosis of the liver cells was observed. Bile canaliculi contained a small quantity of bile thrombi. A few foci of extramedullary hematopoiesis were present in the portal spaces. No inflammatory cell infiltration or necrosis was present. The most conspicuous finding was the formation of the characteristic multinucleated giant cells in the lobules. These giant cells varied in size considerably and measured 15-30 microns in diameter. The majority of these giant cells were multinucleated. The nuclei of the giant cells differed considerably in size, shape and staining intensity, that it was difficult to find out the common character among them (Fig. 1). The cytoplasm of these giant cells was stained acidophilic with hematoxylin-eosin preparation and showed somewhat granular appearance, but no characteristic structure was seen in cytoplasm. There. was no substance stained positively with periodic acid Schiff reaction in the cytoplasm. There was no evidence of phagocytic activity of these giant cells. Lipoid, hemosiderin and bile pigment was not demonstrated in their cell bodies. These giant cells were scattered about irregularly throughout the lobules (Fig. 1). When reticulum fibers were stained with Pap's method, it became evident that many of the giant cells located outside the sinusoid, between sinusoidal wall and liver cells (Fig. 8). Kupffer cells were generally enlarged and occasionally one could find the Kupffer cells with lobulated nucleus which were considered as the transitional form between Kupffer cell and aforementioned giant cell.

The spleen was small, weighing $9 \mathrm{Gm}$., firm and dark red. Microscopically. the advanced congestion was present. Around the very small Malpighian corpuscles few small foci of the hematopoisis were observed.

The kidneys appeared normal on the suface. On section, the medulla, especially the papillae, was coloured brownish yellow and presented the appearance of so-called "bilirubin-infarction". Microscopically, the glomeruli and the convoluted tubuli revealed no pathological changes. A large amount of needle-shaped or 
rhombic brownish yellow crystals and yellow granular pigments were seen in the epithelial cells of collecting tubules and the histiocytes in adjacent stroma.

The bone marrow appeared normal. There was no sign of hyperplasia of myeloic tissues.

The lungs revealed no pathological changes.

The lower half of the mucosa of the esophagus was covered by an opaque membrane which showed icteric colouration. This portion of the esophagus was devoid of epithelial lining and a large amount of brownish yellow krystalline pigments and yellow granular pigments precipitated in the mucosa and submucosa. The submucosa was infiltrated by large number of polymorphonuclear leukocytes and histiocytes, some of which were filled with krystalline and granular pigments.

The same pigments as seen in the medulla of the kidneys and the mucosa of the esophagus was present in the so-called germinal epithelium of the testis, in mucosa of the stomach and in the mononuclear cells in the sinuses of lymphnodes in portal region.

Case 2 (No. 3599): A girl, weighing $2645 \mathrm{Gm}$, was delivered at term by cesarean section. Three days after birth she was jaundiced. Fever was $39^{\circ} \mathrm{C}$ and convulsions were present. The baby died the next day. Her father was of blood group BMN.CDe and her mother of group AMN.CDe. Blood Wassermann reaction of the mother was negative. She had no previous pergnancy. She had never received transfusion of blood or injection of serum.

Necropsy (14 hours after death): The skin and the mucous membranes were moderately janudiced. No edema was present. A few petechial hemorrhages were noticed on the chest.

The brain weighed $380 \mathrm{Gm}$. Except the marked injection of the blood vessels of the meninges, there was no gross abnormality on the surface. On section, the appearance of kernicterus was identical with that of case 1. But in this case, fornix and nucleus nervi occulomotorii, which showed no icteric colouration in case 1 , were coloured deep yellow. The microscopic examination of the yellow stained portions revealed the same findings as in case 1 . In this case the extracellular precipitation of the yellow pigments was very abundant in the floor of the fourth ventricle.

The liver was very small, weighing $90 \mathrm{Gm}$. Microscopically, there were no degenerative changes of the liver cells except moderate degree of fatty degeneration. A small amount of bile thrombi was present in bile canaliculi. In the lobules 
only a few hematopoietic foci were observed. In the portal spaces there was more intense hematopoiesis which was composed of mainly immature granulocytes. Few multinucleated giant cells identical with those seen in the liver of casc 1 were also seen in this case. No inflammatory cell infiltration nor necrosis was present.

'The spleen was small, weighing $6.7 \mathrm{Gm}$. Congestion' of the red pulp was conspicuous. The Malpighian corpuscles were highly reduced in size and number. Around them "moderate hematopoiesis was noticed. Hemosiderosis was inconspicuous.

The macro- and microscopic findings of the kidneys were similar to those of the kidneys of case 1. In some portions the yellow pigments were accumulated in large amount that the structure of the renal tubulus was obscured. Leukocytic reaction was present around these yellow pigment deposits.

The bone marrow appeared normal.

The lungs were grossly normal. Microscopically, there were areas where the alveoli were not expanded. In these areas the narrow alveoli were filled with large mononuclear cells, some of which showed tendency to form the multinucleated giant cells. In some portions focal hemorrhages in groups of alveoli were observed.

The heart showed no gross abnormality. But when the ventricles were opened, many small yellow spots were seen scattered about on the myocardium. Microscopically, there were many areas in myocardium, where an abundant of yellow granular pigments was accumulated in the muscle fibers, in which the cross striation was obscured. No inflammatory cell reaction was noticeable.

The precipitation of the pigments was also seen in the mucosa of the stomach, where the small shallow ulcera were formed.

Case 3 (No. 3509): A boy, weighing $3200 \mathrm{Gm}$., was born at term spontaneously... Twenty four hours after birth he became jaundiced. The icterus increased in intensity more and more. In the next day he became convulsive and fever rose to $39^{\circ} \mathrm{C}$. Death occurred five days after birth. His father was of blood group AMN.CDe and the mother of group AM.cde. Her first child was healthy and the second child died of icterus gravis neonatorum. This case was her third, child. The fourth child died of erythroblastosis fetalis. No kernicterus was found by postmortem examination of this child. Wassermann reaction of maternal blood was negativte.

Autopsy (14 hours after death): The skin and the mucous membranes were intensively jaundiced. Petechial hemorrhage and edema was not present. 
The brain weighed $500 \mathrm{Gm}$. The blood vessels of meninges were strongly injected. On section, the distribution of the jaundiced nuclei was identical with that of the brain of case 2. In addition, a part of nucleus caudatus was stained slightly yellow. Microscopic examination revealed the same finding with that of the aforementioned cases.

The liver, weighing $120 \mathrm{Gm}$., showed icteric colouration which turned to deep green by formalin fixation. Microscopically, fatty degeneration of the liver cells was relatively marked. There was large amount of bile thrombi in bile canaliculi and small bile ducts. Some of the Kupffer cells contained bile pigments. Marked hemosiderosis was present in the peripheries of the lobules. Both in the lobules and in the portal spaces there were many foci of hematopoiesis. In the lobules erythropoiesis was more conspicuous than granulopoiesis and in the portal spaces the latter exceeded the former. Formation of the giant cell was not present.

The spleen was enlarged, weighing $17 \mathrm{Gm}$. Microscopically the advanced congestion was present. Malpighian corpuscles were reduced in size and number. Hematopoiesis was more intensive than that in case 1 and 2. Hemosiderosis was conspicuous.

The kidneys showed the same findings with those of the kidneys of case 1 and 2. A few small foci of erythropoiesis were present at the cortico-medullary junction.

The bone marrow showed proliferation of reticulum cells. The myeloic tissues were rather reduced in amount.

In the lungs, the bronchopneumonia and the focal hemorrhages were evident. In some portions the small abcesses were formed, in which the necrotic masses were coloured with yellow pigments.

The esophagus revealed the same changes with that of the esophagus of case 1 .

Case 4 (No. 3637): A girl, weighing 3390 Gm., was delivered at term spontaneously. Twenty hours after birth she was jaundiced. The icterus increased in intensity rapidly. Vomiting and convulsions were present. Died at the third day of life with an attack of dyspnoea. Her father was of blood group OM.cDE and the mother was of group AN.cdE. The blood Wassermann reaction of the mother was negative. She had no previous pregnancy. She received frequent transfusions of blood previously. 
Autopsy (30 minutes after death): Marked jaundice of the skin and the mucous membranes was present. No petechial hemorrhage and edema was present.

The brain weighed $440 \mathrm{Gm}$. There was a small area of subarachnoideal hemorrhage in the right temporal and occipital region, respectively. On cut surface no hemorrhage was observed. The distribution of the jaundiced nuclei was identical with that of another 3 cases. In this case, some portions of cortex, i.e., a part of gray matter of lobus temporalis and area olfactoria was stained yellow. The microscopic findings were similar to those of aforementioned cases.

The liver, weighing $190 \mathrm{Gm}$, was markedly enlarged. Microscopically the lobules were well preserved. The perisinusoidal space was dilated conspicuously and the liver cell cords reduced in width. Sinusoids themselves were rather small. Only a few fat dropletes were demonstrated in the liver cells. Two types of the liver cells were distinguished concerning the nature of cytoplasm. There were the cells with clear, somewhat vacuolated cytoplasm and the cells with dark homogeneous cytoplasm (Fig. 2). Occasionally it was observed that some of the latter cells fused each other forming an irregularly shaped syncytium. There was marked erythropoiesis in the lobules and granulopoiesis in portal spaces (Fig. 2). There were many giant cells, which were similar to those seen in the liver of case 1 and 2, scattered about in the lobules (Figs. 4-7). In this case, however, some of the giant cells were mononucleated (Fig. 5) and in some instances the cytoplasm was stained deep red by eosin and contained substances stained positively by periodic-acid Schiff reaction, which was not seen in the giant cells in case 1 and 2. Occasionally a transitional form between these giant cells and the above mentioned syncytial fused liver cells was observed (Fig. 6). Bile thrombi were scanty.

The spleen, weighing $35 \mathrm{Gm}$., was markedly enlarged. Advanced congestion was present. Malpighian corpuscles were very small. A moderate degree of hematopoiesis was observed, around them. Hemosiderosis of reticulum cells was outstanding.

Macro- and microscopic findings of the kidneys were similar to those of foregoing cases.

The bone marrow showed normal appearance.

In the lungs few focal hemorrhages were present.

Some portions of the mucous membrane of the colon and the mesenterial lymph-nodes were stained yellow. 


\section{SUMMARY OF FOUR CASES OF KERNICTERUS}

1) Clinical findings (Table I).

Table I

Clinical Findings of 4 Cases of Kernicterus

\begin{tabular}{|c|c|c|c|c|}
\hline Autopsy No. & $\begin{array}{c}\text { Case } 1 \\
3493\end{array}$ & $\begin{array}{c}\text { Case } 2 \\
3599\end{array}$ & $\begin{array}{c}\text { Case } 3 \\
3509\end{array}$ & $\begin{array}{l}\text { Case } 4 \\
3637\end{array}$ \\
\hline Sex & 今 & 古 & 今 & 古 \\
\hline Days of survival & 7 days & 4 days & 5 days & 3 days \\
\hline $\begin{array}{l}\text { Body weight at } \\
\text { birth }\end{array}$ & $2220 \mathrm{Gm}$ & $2645 \mathrm{Gm}$ & $3200 \mathrm{Gm}$ & $3330 \mathrm{Gm}$ \\
\hline $\begin{array}{l}\text { Icterus occurred } \\
\text { at }\end{array}$ & 6 th day & 3 ird day & 1 st day & 1 st day \\
\hline $\begin{array}{l}\text { Blood group } \\
\text { Father } \\
\text { Mother }\end{array}$ & $\begin{array}{l}\mathrm{OM} \cdot \mathrm{CDe} \\
\mathrm{BM} \cdot \mathrm{CDe}\end{array}$ & $\begin{array}{l}\text { BMN. CDe } \\
\text { AMN. CDe }\end{array}$ & $\begin{array}{l}\text { AMN. CDe } \\
\text { AM. cde }\end{array}$ & $\begin{array}{l}\text { OM. cDE } \\
\Lambda \mathrm{N} . \mathrm{cdE}\end{array}$ \\
\hline $\begin{array}{l}\text { Siblings of pre- } \\
\text { ceeding and } \\
\text { subsequent } \\
\text { pregnancies }\end{array}$ & $\begin{array}{l}1 \text { st pregnacy: } \\
\text { still birth } \\
\text { 2nd pregnancy: } \\
\text { abortion at the } \\
4 \text { th mon. } \\
3 \text { rd baby: } \\
\text { this case }\end{array}$ & $\begin{array}{l}1 \text { st baby: } \\
\text { this case }\end{array}$ & $\begin{array}{l}1 \text { st Baby : } \\
\text { healthy } \\
\text { 2nd baby: } \\
\text { died of icterus } \\
\text { gravis neo- } \\
\text { natorum } \\
3 \text { rd baby: } \\
\text { this case } \\
4 \text { th baby: } \\
\text { died of erythro- } \\
\text { blastosis fetalis } \\
\text { (without kernic- } \\
\text { terus) }\end{array}$ & $\begin{array}{l}1 \text { st baby: } \\
\text { this case }\end{array}$ \\
\hline $\begin{array}{l}\text { Wassermann } \\
\text { reaction of } \\
\text { maternal blood }\end{array}$ & Ht & - & - & $\begin{array}{l}\text { The mother had } \\
\text { received frequent } \\
\text { transfusion of } \\
\text { blood previously }\end{array}$ \\
\hline
\end{tabular}

Though it was unable to examine the blood group of the infants, it was evident from Table I, that in case 3 and 4 Rh-incompatibility had existed between mother and child. Histologic examination of these cases showed that these cases had to be diagnosed as erythroblastosis fetails. Erythroblastosis fetalis could be excluded in case 1 and 2. Of the Rh-compatible cases ( case 1 and 2), one was a premature infant delivered at the thirty fifth week of gestation and the other, weighing $2645 \mathrm{Gm}$. at birth, showed the evidences of prematurity. In Rh-incompatible cases (case 3 and 4) the infants seemed well and mature. Icterus occurred within twenty-four hours after birth in Rh-incompatible cases and was very severe, while in Rh-compatible cases icterus occurred at the third and sixth day of life, respectively, and was not intense. 
2) The brain (Table II).

Table II

Distribution and Intensity of Nuclear Staining in 4 Cases

\begin{tabular}{|c|c|c|c|c|}
\hline Autopsy No. & $\begin{array}{c}\text { Case } 1 \\
3493\end{array}$ & $\begin{array}{c}\text { Case 2 } \\
3599\end{array}$ & $\begin{array}{c}\text { Case } 3 \\
3509\end{array}$ & $\begin{array}{c}\text { Case } \\
3637\end{array}$ \\
\hline Thalamus & + & + & + & + \\
\hline Pars pallida & + & + & + & + \\
\hline Putamen & + & \pm & + & + \\
\hline N. caudatus & - & - & + & - \\
\hline N. hypothalamicus & H & tt & $H$ & $H$ \\
\hline Hippocarnpus & H & H & H & tt \\
\hline Cortex & - & - & - & $H^{*}$ \\
\hline Fornix & - & H & $H$ & $H$ \\
\hline N. n. oculomotorii & & $H$ & ti & +t \\
\hline Floor of 4 th ventricle & $H$ & tt & $H$ & H \\
\hline $\mathrm{N}$. olivaris inf. & +4 & 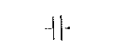 & + & $H$ \\
\hline Nn. cerebelli : & H & H & H & H \\
\hline Anterior gray horn of spinal cord & - & + & + & \pm \\
\hline Plexus chorioideus & $H$ & H & $H$ & $H$ \\
\hline
\end{tabular}

* A part of the gray matter of area olfactoria and lobus temporalis.

As seen in Table II, the distribution and the intensity of nuclear jaundice was essentially the same in all four cases except small variations. The microscopic findings of the yellow stained portions, which were described in detail in case 1, were also the same in all four cases, regardless of existence of $\mathrm{Rh}$-incompatibility. When the icteric portions were examined in Nissl preparation, the yellow pigments had completely disappeared and it was impossible to confirm their localization. But in the areas, where macroscopically the yellow colouration was marked, the degenerative changes of ganglion cells, such as pyknosis, karyorrhexis, karyolysis, chromatolysis, vacuolizations of cytoplasm etc., were conspicuous. The yellow pigments were demonstrated most clearly in frozen sections.

Perivascular cell infiltration and the softening of cerebral substance werc not observed.

3) The liver.

The enlargement of the liver was confirmed only in the case 4 (average value of liver weight of infants $1-30$ days after birth in Japan: m., $145 \mathrm{Gm}$., f., $147 \mathrm{Gm}.)^{(9)}$.

Microscopically, the fatty degeneration of the liver cells was present in each case, but in various degrees. Difference in intensity of the fatty degeneration of 
the liver cells was not established between Rh-compatible and Rh-incompatible cases. Hemosiderosis was more prominent in Rh-incompatible cases than in Rhcompatible cases. Intense extramedullary hematopoiesis in the lobules and the portal spaces was seen in Rh-incompatible cases. In Rh-compatible cases slight or moderate degree of extramedullary hematopoiesis was present almost exclusively in the portal spaces. The hematopoietic foci in the lobules were consisted of chiefly erythroblasts and those in the portal spaces were consisted of chiefly immature granulocytes. Bile thrombi were abundant in case 3 . They were present more or less in the other cases, too.

The giant cell formation was seen in case 1, 2 and 4 (Figs. 1, 3-8). Therefore, it occurred both in Rh-compatible and in Rh-incompatible cases. The giant cells were numerous in case 1. Their formation was less active in case 4, and only a few giant cells were seen in case 2 . The majority of these giant cells were multinucleated, but in case 4 it was not difficult to find out the giant cells with one large round or ovoid nucleus (Fig. 5). The nuclei of the giant cells varied widely in shape and size. Occasionally they were arranged chainlike in the periphery of the cell, which resembled the Langhans type of giant cell (Fig. 3). In some instances the nuclei were lobulated resembling the nuclei of the megakaryocyte (Fig. 4). In some instances the nuclei were shaped quite irregularly and stained homogeneous (Fig. 3), which were considered as a sign of degenerative processes. The nuclear membrane was generally distinct. In general, chromatin nets were coarse, on which dense chromatin granules were scattered. The cytoplasm of these giant cells appeared somewhat granular and stained pink with eosin. But occasionally there were cells which were stained dark red with eosin. The majority of the giant cells was not stained by periodicacid Schiff reaction, but in some instances the material stained intensively red by periodic-acid Schiff reaction was present. Neither lipoid nor hemosiderin was demonstrable in their cytoplasm. There was no evidence of phagocytic activity of these giant cells. There was a transformation from the liver cell to these giant cells (Fig. 6), while some enlarged Kupffer cells with lobulated nucleus were present, which might be interpreted as a transitional form between Kupffer cells and the giant cells (Fig. 7). When reticulum fibers were stained, it was demonstrated clearly that many of giant cells were located outside the sinusoids, between sinusoidal wall and liver cells (Fig. 8).

4) The spleen.

The spleens were enlarged in Rh-incompatible cases, weighing $17 \mathrm{Gm}$. and 
$35 \mathrm{Gm}$, respectively (average value of the weight of spleen of infants $1-30$ days after birth in Japan: m., $13 \mathrm{Gm} ., \mathrm{f} ., 14 \mathrm{Gm}$. $)^{(9)}$. In all four cases advanced congestion was present. The Malpighian corpuscles were reduced in size and number. Extramedullary hematopoiesis was more intense in Rh-incompatible cases than in Rh-compatible cases. Hemosiderosis was very intense in Rhincompatible cases, while it was almost absent in Rh-compatible cases.

5) The kidney.

The pathological changes in the kidney were the same in all four cases. Macroscopically, so-called "bilirubin-infarction" was the constant occurrence. Microscopically, there were abundant yellow granular and brownish yellow crystalline pigments in the epithelial lining of collecting tubules and in histiocytes in adjaccnt stroma. When these pigments were accumulated in excess, the structurc of the tubules was destroyed. In some areas leukocytic reaction was observed about this excessive accumulation of the pigments. Only in the case 3 , a fcw small foci of erythropoicsis were present at the cortico-medullary junction.

6) The bone marrow.

Except in the case 3, in which the proliferation of reticulum cells and the reduction of myeloic tissue was observed, there was no remarkable abnormality in the bone marrow.

7) The lung.

In one case (case 3) the intense bronchopneumonia and in two cases focal hemorhages were present.

8) The icterus.

Though there was a distinct difference between Rh-incompatible and Rhcompatibe cases concerning the clinical course of the icterus, the pathologicanatomic character of the icterus was essentially the same in all four cases, i.c., the kernicterus of the brain, bilirubin-infarction of the kidneys and yellow staining of the mucous membranes of the alimentary canal. As exception, there was yellow staining of myocardium in case 2 and extreme yellow colouration of the lower half of esophageal mucosa in cases 1 and 3 . The yellow colouration of the icteric portions did not turn to green by formalin fixation. Such a characteristic distribution of the icteric portions and resistence of yellow colouration to 
oxydation by formalin are not seen in icterus of adult and in occulsive jaundice of infants.

The yellow colouration of the organs in the cases reported above was attributable to precipitation of yellow granular pigments and brownish yellow cystalline pigments. A mixed proportion of these two types of pigments varied considerably in different organs. In the brain and the heart, there were almost cxclusively the yellow granular pigments, while in the kidneys and esophagus precipitation of the brownish yellow crystalline pigments dominated the picture. These two types of pigments showed several charactericities. These pigments had disappeared or reduced in number in paraffin or celloidin sections, therefore it was necessary to examine with frozen sections in order to study the histochemical character of the pigments. These pigments disappeared or highly reduced in number by addition of chloroform, and reduced in number by addition of ether. In alcohol they were almost insoluble. They were resistent to acid, while in alkali they rapidly disappeared. The yellow granular and brownish yellow crystalline pigments reacted parallel on ábovementioned chemicals. In some portions leukocytic response was present about accumulated yellow pigments.

These pigments were stained negatively by Sudan III and by Berliner blue reaction.

\section{DISCUSSION}

The occurence of kernicterus is very rare in Japan. Prior to 1950 there was no reported case of kernicterus in Japan. In 1951, four cases were reported by us $^{(14)}$ and immediately after our first publication five cases of kernicterus were reported by M. Furuta and S. Kambe(4). Recently M. Furuta and $\mathrm{S}$. Kambe ${ }^{(5)}$ reported another three cases in addition to their first five cases. Therefore, altogether so far twelve cases of kernicterus have been reported in Japan.

A close relation between kernicterus and the erythroblastosis fetails was first mentioned by $v$. Gierke ${ }^{(6)}$. Nowadays many investigators, especially in America, have assumed that kernicterus is specifically related to erythroblastosis fetalis. But recently W. W. Zuelzer and R. T. Mudgett ${ }^{(16)}$ examined fifty-five cases of kernicterus with special reference to the existence of $\mathrm{Rh}$-incompatibility between mother and child and showed evidences that not a few cases of kernicterus was not associated with Rh-incompatibility. They divided the cases of kernicterus into two groups, the Rh-compatible group and the Rh-incompatible group. According their description, the icterus was more severe and occurred eạrier in life in 
Rh-incompatible group than in Rh-compatible group and the majority of the infants of Rh-incompatible group showed the hematologic and histologic evidences of erythroblastosis fetalis, while in Rh-compatible group there were only a few exceptional cases which showed the evidences of erythroblastosis fetalis. Of the four cases of kernicterus reported above, two are associated with erythroblastosis fetalis, while in another two cases no evidences of erythroblastosis fetalis were demonstrable. When the clinical and pathologic-histological findings of these four cases are summarized, it is obvious that, in agreement with the description of W. W. Zuelzer and R. T. Mudgett ${ }^{(16)}$, there are some differences between Rh-incompatible (erythroblastotic) cases and Rh-compatible (non-erythroblastotic) cases.

Of the twelve cases of kernicterus reported in Japan, only two cases are associated with erythroblastosis fetalis. Therefore the incidence of kernicterus without erythroblastosis fetalis is very high in Japan $(83 \%)$. According to W. W. Zuelzer and R. T. Mudgett(16), the incidence of kernicterus without erythroblastosis fetalis is considerably higher in negroes than in white. From this fact it could be assumed, that the high incidence of kernicterus in nonerythroblastotic infants in Japan is related to some racial specifities. But it is well known, that the incidence of Rh-negativity in Japanese is considerably lower than that in white or negroes. C. L. Schneider and C. H. Hughes ${ }^{(11)}$ examined $R h_{0}$ factor on 459 Japanese, in which only seven were $\mathrm{Rh}_{0}$ negative $(1.5 \%)$. This percentage is about one tenths of that of white or negroes. Coincide with this low percentage of Rh-negativity, the incidence of erythroblastosis fetalis is very low in Japan. Accordingly it must be expected that the incidence of kernicterus with eqrythroblastosis fetalis is also very low in Japan. Therefore it seems necessary to study on a larger case material to conclude that the incidence of kernicterus without erythroblastosis fetalis would be actually higher than that of kernicterus with erythroblastosis fetalis in Japan, and then, that the high incidence of kernicterus without erythroblastosis fetalis in Japan would be related to some racial specifities.

In the cases reported above, kernicterus is typical one in its macro- and microscopic findings. The distribution and the macro- and microscopic findings of the jaundiced nuclei of the brain are almost the same in all four cases except small variation (Table II), regardless of existence of erythroblastosis fetalis. It might be noteworthy that the yellow pigments in janudiced nuclei disappear or reduce in number considerably in paraffin or celloidin sections, In frozen 
sections the pigments seem to be well preserved.

Extramedullary hematopoiesis is conspicuous in the liver and spleen in Rh-incompatible cases, which have been diagnosed as erythroblastosis fetalis. In Rh-compatible cases there are also slight or moderate extramedullary hematopoiesis in the liver and spleen, but it is never so conspicuous as in Rhincompatible cases. As mentioned in fore-going paragraphs, the evidences of prematurity are noted in Rh-compatible cases. Because the persistence of extramedullary hematopoiesis is a common occurrence in premature newborns, it may be considered that the hematopoietic foci in the liver and spleen in Rhcompatible cases is a manifestation of prematurity. In case 1 syphilis could not be excluded as a causative factor for persistence of extramedullary hematopoiesis, but in another three cases syphilis is reasonably excluded.

The formation of the giant cells in the liver of case 1,2 and 4 is an unique finding. From the facts, that there is a gradual transition from liver cells and Kupffer cells to these giant cells and that many of them are located outside the sinusoid, it is obvious that these giant cells are formed in the liver itself. Judging from the literatures, marked giant cell formation in the liver is thought to be a very rare occurrence. The discussion about giant cell formation in the liver must be centered at first in the formation of megakaryocytes in the liver. In the so-called "myeloid megakaryocytic hepato-splenomegalia" megakaryocytes are formed and proliferate markedly in the liver and spleen. ${ }^{(3)}$ A part of the giant cells seen in the cases reported above resembles the megakaryocyte in their shape, but there are also many giant cells, which differ from megakaryocyte in their all aspects. While the cytoplasm of megakaryocytes is stained by periodicacid Schiff reaction intensively red, the majority of the giant cells in the cases reported above reacted negatively on this reaction. Furthermore it is impossible to suppose that the megakaryocyte would be transformed from the liver cells. From these points it must be concluded that the giant cells found in the liver of the cases reported above belong to a differnent entity from megakaryocyte. It is reported that occasionally a sort of hepatocellular giant-cell formation is seen in the liver of syphilitic newborn. ${ }^{(8)}$ In such cases the giant cells are ingraved in highly fibrotic tissue resulted from hepatitis interstitialis syphilitica. Though the giant cells seen in the cases reported above are hepatocellular origin, there are no evidences of fibrosis of the liver. Furthermore, of the three cases, in which the giant cells are formed in the liver, two cases are delivered from mother, in whom syphilis is reasonably excluded. Therefore it seems, that syphilis cannot 
account for the formation of giant cells in the liver of the cases reported above. There are only a few descriptions about formation of the giant cells in the liver of erythroblastotic infants. Only v. Gierke ${ }^{(6)}$ and M. Hayashi and A. Watanabe ${ }^{(7)}$ described in a case of erythroblastosis fetalis, respectively, that some of the liver cells became syncytial forming a multinucleated giant cell. Recently J. M. Craig(1) studied the pathologic-histologic changes of the liver in 141 cases of erythroblastosis fetalis, but there is no description about giant cell formation in his report. We examined the slides of the liver of five cases of kernicterus reported by M. Furuta and S. Kambe. No evidence of giant cell formation was found in any case. Because the morphology of the giant cells is not described in detail in the cases of v. Gierke ${ }^{(6)}$ and M. Hayashi and A. Watanabe ${ }^{(7)}$, it is difficult to decide, whether the giant cells seen in the cases reported above are identical with those in the cases reported by v. Gireke ${ }^{(6)}$ and $M$. Hayashi and A. Watanabe ${ }^{(7)}$. But from the fact, that in both instances the giant cells are formed from the syncytial fused liver cells, it can be assumed that the giant cells seen in the cases reported above and in the cases reported by $v$. Gierke ${ }^{(6)}$ and M. Hayashi and A. Watanabe ${ }^{(7)}$ would be included in a same entity. Therefore it would be expected that the giant cell formation is rarely seen in the liver of the infants with severe jaundice, though the causative factors for the formation of the giant cells is completely obscure.

Icterus, which do not turn to green by formalin fixatio, is present in all four cases. In the icteric portions the accumulation of two types of the pigments is demonstrated microscopically, i.e., the brownish yellow crystalline pigments and the yellow granular pigments. The former type of the pigments is thought to be identical with hematoidin from its morphological and histochemical characteristics. The latter type of the pigments, which precipitate alone or intermingled with the former pigments, react parallel with the former pigments on acid, alkali and some organic solvents. But in some morphological aspects, the yellow granular pigments differ obviously from usual hematoidin or bilirubin. Because chemical analysis of the pigments could not be performed, it was difficult to determine the chemical nature of these pigments. But it may be supposed, that these pigments are a modified bilirubin or a pathologic production, which has been formed in the course of the formation or the destruction of hemoglobin.

The causative factor for kernicterus has not been clearly demonstrated. But, in authers' opinion, it is noteworthy that kernicterus is always associated with the formation of above mentioned specific yellow granular pigments regardless of the cxistence of erythroblastosis fetalis. Nowadays many investigators tend to deny 
the specifity of the icteric pigment as a causative factor for kernicterus. Though there are some experimental (2) and pathologic-anatomical data ${ }^{(17)}$ indicating that kernicterus would occur in usual hyperbilirubinemia, the possibility could not yet be excluded that a specific icteric pigment formed in neonatal stage plays a possible role in the pathogenesis of kernicterus.

\section{SUMMARY}

1) The authors reported four cases of kernicterus occurred in Japan.

2) The incidence of kernicterus is very low in Japan. Only twelve cases of kernicterus, including the cases reported above, have been reported in Japan.

3) Of the four cases reported above, two cases were associated with erythroblastosis fetalis and in another two cases erythroblastosis fetalis could be reasonably excluded.

4) Of the twelve cases of kernicterus reported in Japan, ten cases were not associated with erythroblastosis fetalis $(83 \%)$. It is supposed that such high incidence of kernicterus without erythroblastosis fetalis would be related to some racial specifities.

5) In agreement with W. W. Zuelzer and R. T. Mudgett ${ }^{(16)}$, some differences were noticeable between the cases of kernicterus with erythroblastosis fetalis and those without erythroblastosis fetalis concerning the clinical and pathologic-anatomic findings.

6) The formation of the characteristic giant cells was observed in the liver in three cases. These giant cells were considered to originate from both liver cells and Kupffer cells. These giant cells differ from megakaryocyte and the giant cell seen in the liver of syphilitic newborn. Only a few descriptions about giant cell formation in the liver, which was thought to be identical with that seen in the cases reported above, were available. The pathological significance of these giant cells is not clear, but there are some evidences showing that these giant cells are occasionally formed in the liver of newborns with severe icterus.

7) The role of a specific icteric pigment in pathogenesis of kernicterus cannot be excluded.

I would like to express our gratitude to Dr. T. Furuhata, professor of medical jurisprudence, Tokyo University School of Medicine, for his invaluable help for the determination of blood group and to Dr. M. Furuta and Dr. S. Kambe, pathologists to ABCC in Hiroshima, who kindely permit us to examine their slides of the cases of kernicterus. 


\section{REFERENCES}

1. Craig, J. M. Sequences in the development of cirrhosis of the liver in cases of erythroblastosis, Arch. Path. 49, 665-686, 1950.

2. Day, R.: Kernicterus problem: Experimental in vivo and in vitro staining of brain tissue with bilirubin. Am. J. Dis. Child., 73, 241, 1947, cit. by W. W. Zuelzer and R. T. Mudgett.16)

3. Downey, $H$. and Nordland, M.: Hematologic and histologie study of a case of mycloid megakaryocytic hepato-splenomegaly, Fol. haemat., 62, 1-39, 1939.

4. Furuta, M. and Kambe, S.: Five cases of kernicterus without demonstrable erythroblastosis. Trans. Soc. Path. Jap., 40 (editio regionalis), 244-250, 1951.

5. Furuta, M. and Kambe, S.: 41st Committee of the Japanese Pathological Society, 1952.

6. v. Gierke: Ueber fötale Erythroblastose, Virch, Arch., 275, 330-347, 1929.

7. Hayashi, M. and Watanabe, A.: Hampatsu-sei taizisuisyu ni tsuite, Rinsho Hujinka Sanka, 3, 367-369, 1949. (Japanese)

8. Oppenheimer, R.: Riesenleberzellen bei angeborener Syphilis, Virch. Arch., 182, 237$257,1905$.

9. Sato, B. and Aimi, S.: Studies on the normal weight of persons dying of unnatural death, Trans. Soc. Path.' Jap., 39, 338-341, 1950. (Japanese)

10. Schmorl, G.: Zur-Kenntnis des Icterus neonatorum, insbesondere der dabei auftretenden Gehirnveränderungen, Verh. deut. path. Ges., 6. Tag., 109-115, 1903.

11. Schneider, C. L. and Hughes, C. H.: Nippon ni okeru Rh inshikei, Igaku no Ayumi, 7, 118-121, 1949. (Japanese)

12. Vaughan, V. C.: Kernicterus in erythroblastosis fetalis, J. Pediat., 29, 462-473, 1946.

13. Vaughan III, V. C., Allen Jr., F. H. and Diamond, L. K.: Erythroblastosis fetalis. IV. Further observation on kernicterus, Pediat., 6, 706-716, 1951.

14. Watanabe, Y., Kobayashi, I. and Sakaguchi, H.: Report of 4 cases of so-called "kernicterus", Trans. Soc. Path. Jap., 40 (editio regionalis), 57-59, 1951. (Japanese)

15. Wiener, A. S. and Brody, M. Pathogenesis of kernicterus, Science, 103, 570, 1946.

16. Zuelzer, W. W. and Mudgett, R. T.: Kernicterus. Etiologic study based on an analysis of 55 cases, Pediat., 6, 452-472, 1950.

17. cit. by W. W. Zuelzer and R. T. Mudgett, ${ }^{16)}$

Oda, T.: In the discussion to 4 ).

\section{MICROPHOTOGRAPHS}

Fig. 4. The liver of case 4 (H-E., oil immersion)

A giant cell with a large, lobulated nucleus resembling the megakaryocyte.

Fig. 5. The liver of case 4 (H-E., oil immersion)

Three giant cells gathering in a dilated perisinusoidal space. Two of them are mononucleated.

Fig. 6. The liver of case 4 (H-E., high power magnification)

A transitional form between the multinucleated giant cell and the syncytial fused liver cells.

Fig. 7. The liver of case 4 (H-E., oil immersion)

An elongated giant cell which is considered as a transitional form between the giant cell and the Kupffer cell.

Fig. 8. The liver of case 1. (Pap's reticulum stain, high power magnification)

It is clearly demonstrated that the two giant cells located outside the sinusoidal wall. 

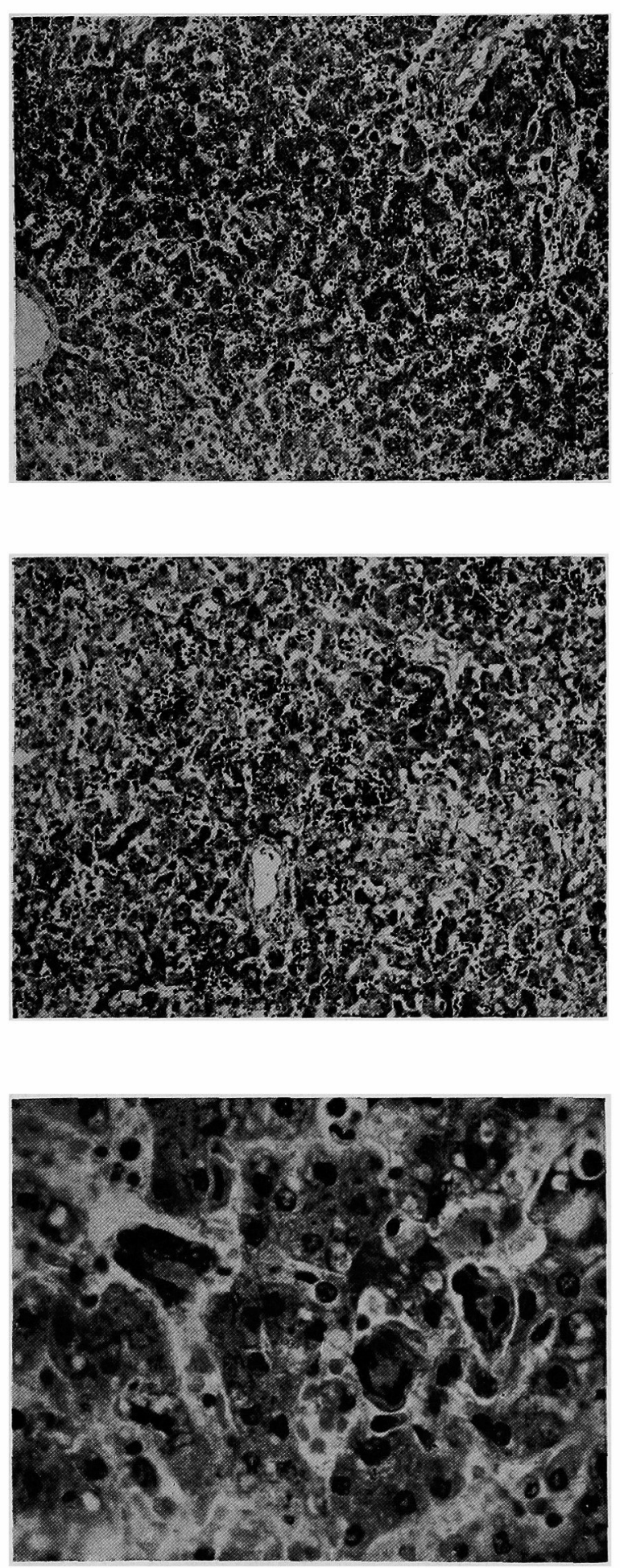

Fig. 1

The liver of Case 1. (H.E., low power magnification). Many giant cells are scattered about in the lobules.

Fig. 2

The liver of Case 4. (H.E., low power magnification). Many foci of erythropoiwsis are seen in the lobules.

Fig. 3

The liver of Case 1. (H.E., high power magnification). Three giant cells are visible. Two giant cells seen in the right half of the photograph have irregularly shaped homogeneous nuclei, which are considered as degerated giant cells. A giant cell seen in the left half resembles the giant cell of Langhans type. 


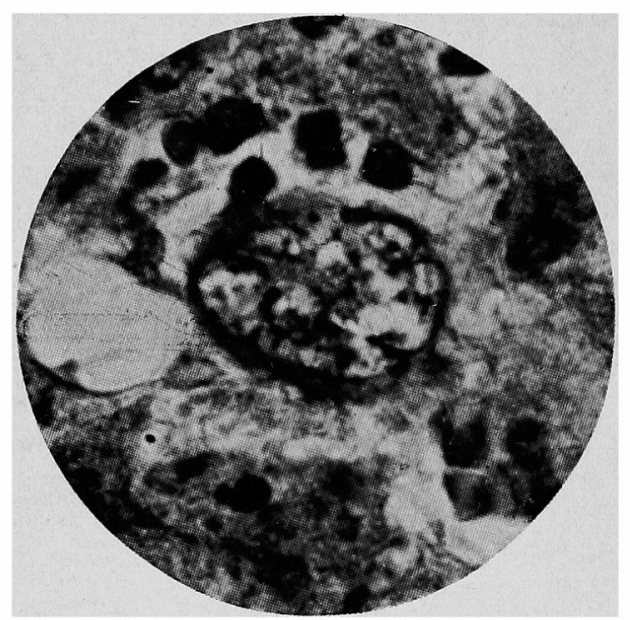

Fig. 4

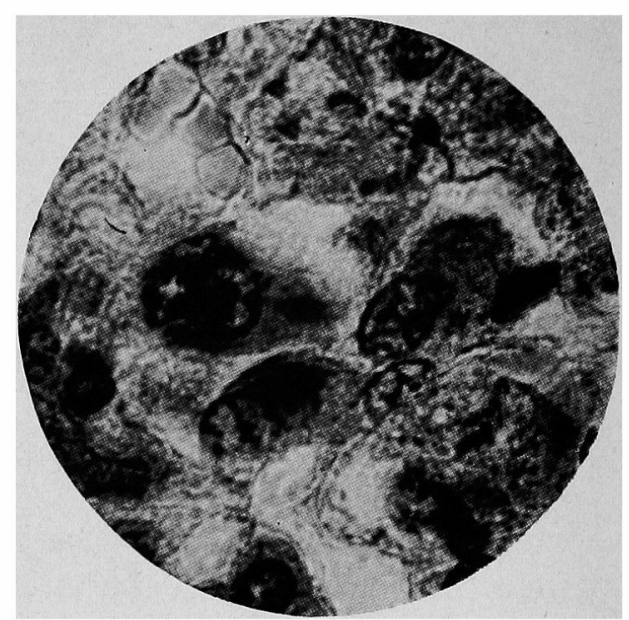

Fig. 5

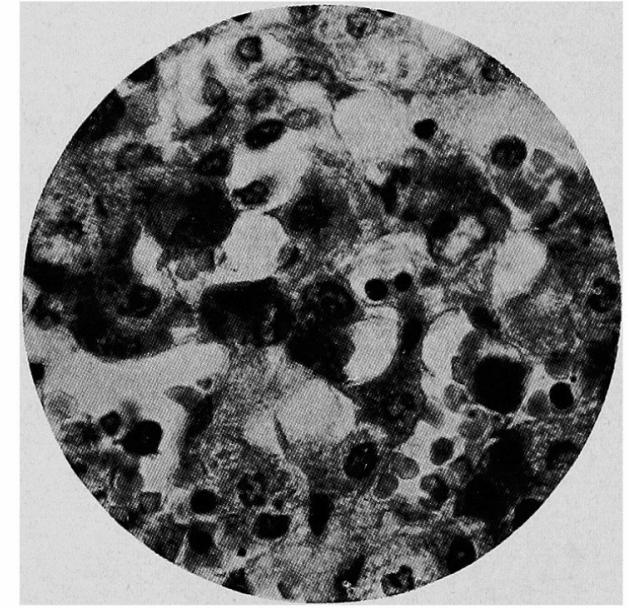

Fig. 6

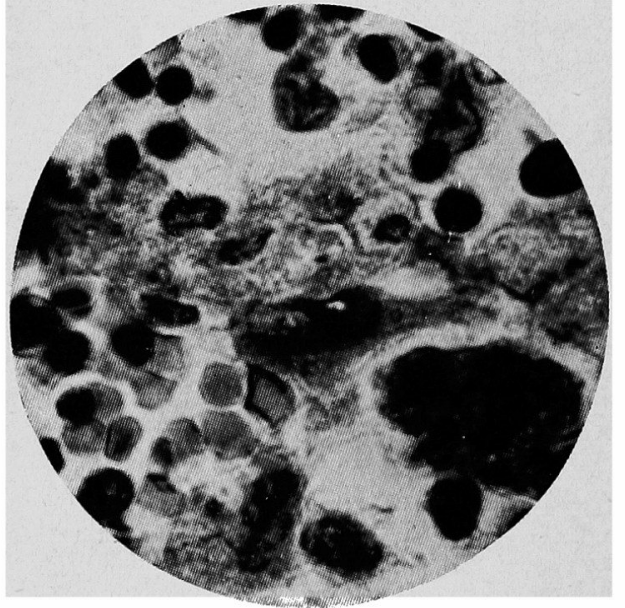

Fig. 7

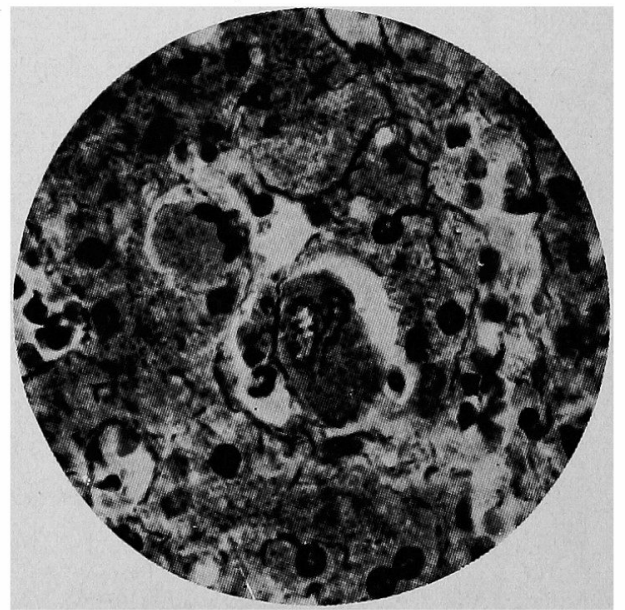

Fig. 8 